\title{
EXODUS 32 AND THE FIGURE OF MOSES IN TWELFTH-CENTURY THEOLOGY
}

\begin{abstract}
This article discusses why twelfth-century theologians were particularly interested in examining Exodus 32, and the event of Moses's intercession for the Israelites. Although it had not markedly troubled earlier commentators, scholastic masters such as Robert of Melun and Peter Comestor were wary of the fact that Moses had appeared to offer up his own salvation in exchange for the salvation of the sinful Israelites. On one reading, this could suggest that Moses was willing to risk his own salvation and challenge the divinely-ordained order of salvation and damnation. A number of strategies were thus devised to explain Moses's actions and account for his words, clarifying how his act of intercession could be reconciled with a medieval vision of soteriological justice.

Considering the reasons why this passage caused such interpretative difficulties, and the multiple strategies by which scholastic masters sought to overcome those difficulties, offers insight into one of the central concerns of twelfth-century theology: namely, to identify the difference between biblical examples to be imitated and those to be avoided. There is a clear parallel between scholastic examination of Moses's behaviour, and twelfth- and thirteenthcentury anxieties over scriptural justification of the judicial ordeal.
\end{abstract}

\section{INTRODUCTION}

When considering the significance of the figure of Moses in medieval literature, he has traditionally been understood as model for leadership. Throughout the Middle Ages, the iconography of the Old Testament patriarch appealed to both secular and ecclesiastical rulers. To Roman Christian emperors, whose own authority was both hedged with divinity and grounded de iure, the model of Moses provided a means of blurring the distinction between a divinely-appointed leader and a secular lawgiver. ${ }^{1}$ Almost a millennium later, Thomas Aquinas saw in Moses's rule over Israel an experiment in creating the best form of Aristotelian polity. ${ }^{2}$ Renaissance humanists too, claimed Moses as one of their own: a man

\footnotetext{
${ }^{1}$ Claudia Rapp, 'Comparison, Paradigm and the Case of Moses in Panegyric and Hagiography', in Mary Whitby (ed.), The Propaganda of Power: The Role of Panegyric in Late Antiquity (Leiden: Brill, 1998), pp. 277-98, esp. 286-92. For late antique views of Moses as a forerunner of Christ see J. Edgar Burns, 'The Agreement of Moses and Jesus in the "Demonstratio Evangelica" of Eusebius', Vigiliae Christianae 31 (1977), pp. 117-25: e.g. as Moses parted the waves and walked through the sea, Jesus walked upon it; where Moses fed the people with manna, Jesus fed them with loaves and fishes; where Moses brought the Israelites to the Promised Land, Jesus leads man to the kingdom of heaven.

2 Douglas Kries, 'Thomas Aquinas and the Politics of Moses', The Review of Politics 52:1 (1990), pp. 84-104.
} 
who was at once warrior, saint, liberator, and theologian. ${ }^{3}$ Even Machiavelli, the most critical of judges, found in Moses a man after his own heart, as a leader who loved his patria more than his own soul, and would go to any lengths to deliver the people of Israel. ${ }^{4}$

In short, the exempla that could be drawn from Moses's life provided great scope for authors, theologians and artists. Viewing Moses through the lens of twelfth-century theology, however, brings into view an undiscussed episode in the history of biblical interpretation. From the early twelfth century onwards, scholastic theologians in cathedral schools began to raise doubts about the disreputable model which certain incidents in the life of Moses might present to contemporary leaders. The ways in which these theologians wrestled with the apparent improprieties of a biblical patriarch reveal a hitherto overlooked series of arguments concerning the nature of order, hierarchy and salvation. Examining those questions, moreover, provides considerable insight as to how masters of theology understood the relationship between scripture and contemporary society, and their role in mediating between the two. It is their overwhelming concern with divine justice and soteriology which marks scholastic theology as taking an approach distinctly different from that of earlier exegetes; an exegetical attitude which speaks to peculiarly scholastic concerns about how scripture should be understood and utilised.

The root of the theological troubles concerning Moses can be traced to a single episode in the life of the patriarch, Exodus 32:19-34. This was the sequence of events in which the Israelites create, and then begin to worship, a false idol in the shape of a golden calf, during Moses's absence. ${ }^{5}$ On discovering this transgression, Moses's response was twofold. He first summoned all the loyal men ('Levites', filii Levi, is the Vulgate's

\footnotetext{
${ }^{3}$ Vivien Gaston, 'The Prophet Armed: Machiavelli, Savonarola, and Rosso Fiorentino's Moses Defending the Daughters of Jethro', Journal of the Warburg and Courtauld Institutes 51 (1988), pp. 220-25.

${ }^{4}$ See John H. Geerken, 'Machiavelli's Moses and Renaissance Politics', Journal of the History of Ideas 60 (1999), pp. 579-95.

${ }^{5}$ For a commentary, see William Henry Propp, Exodus 19-40: A New Translation with Introduction and Commentary (New York: Doubleday, 2006), pp. 329-34.
} 
description) from the camp, and instructed them to put to the sword all the idolaters who remained within, sparing none. After three thousand had been slain, Moses told the Levites that the Lord blessed their actions. ${ }^{6}$ The following day, Moses went to intercede with God, imploring him not to condemn the Israelites for their idolatry. Moses admitted that the people had committed a great sin, but proposed a bargain, asking 'either forgive their sin, or blot me out of the book you have written' (in the Vulgate: aut dimitte eis hanc noxam aut si non facis dele me de libro tuo quem scripsisti). ${ }^{7}$

Even today, the interpretation of this passage continues to present a number of difficulties for the exegete. Recent scholarship, for example, has suggested that this presents a model for intercessory prayer: God invited Moses to make intercession for the Israelites, and expected Moses to argue against him. ${ }^{8}$ Early scholastic commentators identified two particular problems in explicating this passage. The first lay in deciphering exactly what was meant by the phrase 'the book which you have written', libro tuo quem scripsisti. When mentioned elsewhere in scripture, such a book seems to refer to a record of the deeds of righteous and the wicked kept by God, according to which humankind would be judged. Following the description in Psalm 158, this book was also known as the Book of Life (libro vitae or libro viventium). ${ }^{9}$ For twelfth-century readers, however, the term libro vitae denoted far more than a simple record of good and wicked deeds: it signified the book in which the names of those whom God had predestined to heaven were written. ${ }^{10}$ When considered in these terms, Moses's words seemed to represent a demand to have his predestined salvation revoked, and a request for the Lord to undo what he himself had commanded. This

\footnotetext{
${ }^{6}$ Ex. 32:25-29.

${ }^{7}$ This, and all subsequent biblical quotations, are taken from the New International Version (2011).

${ }^{8}$ For modern theologians' readings of this passage see Michael Widmer, Moses, God and the Dynamics of Intercessory Prayer: A Study of Exodus 32-4 and Numbers 13-14 (Tübingen: Mor Siebeck, 2004), pp. 129-41. ${ }^{9}$ Psalm 158:9, 'may they be blotted out of the book of life (libro viventium) and not be listed with the righteous', cf. Daniel 12:1-2; Philippians 4:3; Revelation 3:5, 13:8.

${ }^{10}$ e.g. Hugh of St. Victor, Explanatio in Canticum beatae Mariae, PL 175:430C. For the developments of this idea in pre-scholastic theology, see Rosamund McKitterick, History and Memory in the Carolingian World (Cambridge: Cambridge University Press, 2004), pp. 162-63.
} 
proposition was an awkward one, to say the least. The second exegetical complication for the medieval interpreter arose from the silence of scripture, which does not explicitly state how the Lord responded to this request. Subsequent chapters, whilst noting that a plague was visited on the Israelites as punishment for their idolatry, do not answer the fundamental question of whether Moses's intercession had secured the salvation of their souls. As will be seen, twelfth-century commentators also struggled with the ambiguity of this passage:

The Lord replied to Moses, "whoever has sinned against me I will blot out of my book. Now go, lead the people to the place I spoke of, and my angel will go before you. However, when the time comes for me to punish, I will punish them for their sin". And the Lord struck the people with a plague because of what they did with the calf Aaron had made. ${ }^{11}$

Exodus 32 was thus both a crucial passage for understanding questions of predestination, but also a profoundly ambiguous topic for exegesis. For medieval exegetes, this entailed considering whether Moses's apparent request to have his own salvation set aside was a legitimate and morally righteous request in the first place. The theologians of the twelfth century, in particular, were receptive to the potential for interpreting the historical events narrated in the Old Testament as didactic political exempla. ${ }^{12}$ The actions of Moses were no exception to this process.

Just as significant - historically and theologically - is the fact that twelfth-century theologians were the first scholars to consider the problems and potential ramifications of Exodus 32 in depth. Moses's intercession was the subject of some of the thorniest theological quaestiones and disputationes produced during the theological flourishing of the TwelfthCentury Renaissance. Patristic authorities, by contrast, had not singled out this incident as an unusually difficult passage for interpreters. ${ }^{13}$ Augustine, for example, had considered the

\footnotetext{
${ }^{11}$ Ex. 32:33-35.

${ }^{12}$ Cf. Avrom Saltman, 'John of Salisbury and the World of the Old Testament', in M. Wilks (ed.), The World of John of Salisbury (Oxford: Blackwell, 1984), pp. 343-63.

${ }^{13}$ For example, it is not considered by Ambrosiaster in his Quaestiones Veteris Testamenti, PL 35 (listed by Migne amongst the works of Augustine), nor by Isidore of Seville, although he does examine the significance of the preceding incident, the slaughter of the 3000: Quaestiones in Vetus Testamentum; PL 83:306B-307C.
} 
issue of Moses's intercession in his Quaestiones in Heptateuchum (c. 419-20), but his

treatment of the incident was brief, and, in keeping with the theme of that work, Augustine was primarily concerned with matters of language and expression. ${ }^{14}$ Augustine was interested in examining the logic and form of Moses's words, and noted that having said 'either forgive their sin or delete me from the Book of Life', it would follow that if God did not 'delete' Moses, he would pardon the Israelites. ${ }^{15}$ Augustine concluded that this was indeed what happened: as Moses was not deleted from the Book of Life, so it should be understood that the sins of the Israelites were remitted (remittere) by God.

For Gregory the Great, meanwhile, the salient point for exegetes expounding Exodus 32 was not justice, but Moses's steadfast behaviour in the face of divine anger. Gregory had raised the question in his Moralia in Iob, when glossing the scriptural description of 'God, whose anger no-one is able to resist' (Job 9:13). ${ }^{16}$ Yet, Gregory observed, pointing to Exodus 32:32, it seems that Moses had managed to resist divine anger when suing for the idolatrous Israelites. For Gregory, this placed Moses in a special category of biblical figures who had attempted to resist the wrath of the Lord, alongside Aaron, King David and Elias. ${ }^{17}$ Gregory ultimately resolved the difficulty of an individual resisting divine wrath by explaining that, as these men were saints, they could not truly have been described as 'resisting' God. Each of them held within them an element of the divine power, and thus they did not oppose their wills to God's own, but simply faced down the external power of the Lord through that part of his power which was contained within them. The appeasement of divine anger in these instances, Gregory explained, was only possible because God had willed it. However, when

\footnotetext{
Isidore is more interested in linking the episode of the Golden Calf to the three categories of sin - in deed, in word and in thought (aut facio, aut verbo, aut cogitatione committitur). Bede, following Isidore, recounts the incident of the golden calf, the slaughter of the 3000, and their three-fold sin, but makes no mention of the intercession: In pentateuchum commentarii, PL 91:330B-D.

${ }^{14}$ Augustine, Quaestiones in Heptateuchum, 147; PL 34:645.

${ }^{15}$ Quaestiones in Heptateuchum, PL 34:645, 'securus quidem hoc dixit, ut a consequentibus ratiocinatio concludatur; id est, ut quia Deus Moysen non deleret de libro suo, populo peccatum illud remitteret'.

${ }^{16}$ Gregory, Moralia in Job, 9.16.23; ed. M. Adriaen, CCSL 143 (3 vols., Turnhout: Brepols, 1979-85), i, p. 473.

${ }^{17}$ For Aaron, Numbers 25:11; David, 2 Sam. 2:24-5; Elias, 1 Kings 18:44.
} 
the Lord truly roused himself to vengeance, nothing could be done to stop it. On the subject of intercession, Gregory added as a general comment that those who attempt to sway the divine wrath against their people often end up bringing it upon themselves. It was for this reason - his offer of taking his people's punishment on himself - that Moses never lived to see the Israelites enter the Promised Land. Gregory suggested that although God did not remove Moses's name from the Book of Life, he did punish him in some sense for his audacity. King David had suffered similarly for his intercession, never being able to abate the anger of the Lord against him (2 Samuel 24:10). ${ }^{18}$

Pre-scholastic interpretations of Exodus 32 broadly follow the lines traced out by Gregory the Great, concentrating on the question of divine anger. The ninth-century Carolingian exegete, Rabanus Maurus followed Gregory in agreeing that the inherent difficulty in interpreting this passage lay in its apparent challenge to the irresistible, unappeasable power of divine anger. ${ }^{19}$ He made reference to Exodus 32:10, where the Lord had told Moses 'leave me alone so that my anger may burn against them'. But how was this to be reconciled with Exodus 32:31-32, in which Moses pleaded for the forgiveness of his people? Rabanus drew on and developed a passage from Gregory's Moralia, which compared Moses's action to that of Phinehas (Numbers 25). Phinehas, the high priest of Israel, discovered that one of his people had brought a Midianite woman into the camp and fornicated with her. Phinehas's zealous and immediate response was to slay both the man and the woman. Thanks to this rapid intervention, the Lord averted the plague he had intended to inflict upon Israel, and Phinehas's descendants were appointed to the priesthood in perpetuity. ${ }^{20}$ It may seem a rather surprising strategy to link Phinehas's killing of two sinners with Moses's intercession for the forgiveness of a sinful people, but Gregory and Rabanus

\footnotetext{
${ }^{18}$ Gregory, Moralia in Job, 9.16.23, i, pp. 473-4.

${ }^{19}$ Rabanus Maurus, Commentariorum in Exodum Libri Quatuor, 4.17; PL 108:223-26.

${ }^{20}$ Commentariorum in Exodum Libri Quatuor, 4.17; PL 108:223.
} 
considered these actions according to their ends: both Phinehas and Moses had acted as they did in order to placate divine anger against their people.

These patristic and Carolingian commentaries on Exodus were preserved and examined in the schools of the late eleventh and early twelfth centuries, where the authoritative patristic readings of scripture provided the foundations for the Glossa ordinaria, the first complete medieval gloss on the Bible. ${ }^{21}$ The treatment of Exodus 32 in the Glossa ordinaria is limited: though the gloss is systematic, it is brief, and it is hardly the place to seek a cutting-edge dialectical exposition of scripture. The Glossa refers Augustine's point on the consequent logic of Moses's 'either... or' statement, but its commentary essentially follows Gregory the Great, reiterating the problem of a holy man setting himself against God's anger. ${ }^{22}$ In general, however, the Glossa ordinaria does not provide an instructive demonstration of why Moses's intercession engaged scholastic imaginations, nor of the importance of dialectical logic in attempting to resolve this scriptural puzzle. For some indication of how masters in the schools answered this question, and, more significantly, why they were so interested in this passage, it is necessary to turn to quaestiones and disputationes from the schools. It is significant that Exodus 32 was considered - despite the discussions provided by patristic exegesis - a passage which required explanation in a body of literature typically reserved for considering the meaning of the most testing and difficult parts of scripture.

\section{THE FIGURE OF MOSES IN THE TWELFTH CENTURY}

For a broadly representative example of how twelfth-century scholastic theologians approached the intercession of Exodus 32, the best guide is a minor series of quaestiones

\footnotetext{
${ }^{21}$ Cf. L. Smith, The Glossa ordinaria: The Making of a Medieval Bible Commentary (Leiden: Brill, 2009).

${ }^{22}$ Glossa ordinaria on Exodus 32, PL 114:474.
} 
attributed to the Augustinian canon Hugh of St Victor (c. 1096-1141), although that ascription is not certain. ${ }^{23}$ Even on an initial reading, it is immediately apparent that Hugh's method is markedly different to that of his patristic and Carolingian predecessors. Rather than address Exodus 32 in relation to divine anger, as was traditional, Hugh links the passage to a series of questions on caritas. Hugh was particularly interested in considering the order of caritas, i.e. the different duties of love imposed on individuals according to their relationship with society and with God. ${ }^{24}$ Hugh begins from a fairly basic range of biblical quotations which instruct humankind on who and how to love, such as 'love your neighbour as yourself' (Matt. 22:39; Mark 12:31), and 'he who loves his father or mother more than me is not worthy of me' (Matt. 10:37). Love of God sits atop this hierarchy of rightly-ordered loves. The question raised for Hugh by Exodus 32, then, is how Moses's intercession is to be fitted into that order of love. Hugh recognises that a straightforward reading of the passage would seem to argue that Moses loved the salvation of his people more than the salvation of his own soul; an example which would defy the hierarchy of loves which Hugh has constructed. The quaestio seeks to provide some resolution of this apparent contradiction.

Hugh's discussion begins with some fairly basic propositions concerning caritas, in keeping with earlier patristic and medieval arguments on this point: ${ }^{25}$ caritas is only properly ordered when we first love God, and then our neighbour. We are to love God on his own account, whilst our neighbour we love on account of God. With this statement, Hugh arrives at a consideration of Exodus 32. Why did Moses ask God to spare his sinful people, or else demand he be deleted from the Book of Life? Why would Moses willingly sacrifice his own

\footnotetext{
${ }^{23}$ O. Lottin, 'Questions inédites de Hugues de Saint-Victor', Recherches de théologie ancienne et médiévale 27 (1960), pp. 54-6.

${ }^{24}$ On the genesis and development of this idea, G. Constable, "Love and Do What You Will”: The Medieval History of an Augustinian Precept (Kalamazoo, MI: Medieval Institute Publications, 1999).

${ }^{25}$ For the history of the idea, see Hélène Pétré, Caritas: Etude sur le vocabulaire latine et de charité chrétienne (Louvain, Spicilegium Sacrum Lovaniense, 1948). For the importance of caritas as a mediating principle when enforcing ecclesiastical law in this period, B.C. Brasington, 'Lessons of Love: Bishop Ivo of Chartres as Teacher', in Sally N. Vaughan and Jay Rubenstein (eds.), Teaching and Learning in Northern Europe 10001200, (Turnhout: Brepols, 2006), pp. 129-47.
} 
eternal beatitude? Moses's words, Hugh notes, seem to indicate that he placed the salvation of the Israelites above his own. Yet salvation, reunion with God, is the greatest good for humankind, and the thing humankind ought to most desire. To place anything before one's own salvation is to overturn the order of love as Hugh has constructed it.

At this point in his answer, Hugh was faced with several possible explanatory strategies. He might have chosen to defend Moses's intercession by creating some exception in the ordo caritatis, setting up Exodus 32 as an historical special case. Alternatively, Hugh could have chosen to condemn Moses for his words, although this would have required him to criticise the great law-giver. Finally, Hugh could attempt to reinterpret the problem passage, preserving both his respect for Moses as a virtuous patriarch and his own scheme of the ordering of caritas. He chose this latter option, stating, flatly, that Moses never attempted to exchange his own salvation for that of the Israelites. The key to the correct understanding of this passage is that these words cannot be interpreted literally, as Moses had uttered them. 'Locutio fuit, non sensus', Hugh explains: these were the words, but not the meaning Moses intended by them.

Hugh developed the distinction between Moses's words and his true meaning with reference to a contemporary analogy: when men seek the goodwill of their lords, they do not pause to select words nor to shape the form of their speech. So keen are petitioners to win favour that they show no concern for precision of language. The same was true of Moses interceding before the celestial Lord for the Israelites. What Moses had expressed was not an ultimatum, but simply his faith in the mercy of God. The import of his words was as follows, Hugh explains: 'just as I am certain that you will not kill me, be certain that I want you to spare them'. And again: 'just as I am certain of your justice, by which you will reward me for my good deeds, so I am certain of your mercy, by which you will spare the people'. ${ }^{26}$ In

\footnotetext{
${ }^{26}$ Lottin, 'Questions inédites', p. 55.
} 
Hugh's interpretation, rather than imploring God for mercy and offering his own soul as a bargaining chip, Moses had done nothing more than aver that he was as certain that God would forgive his sinful people as he was confident of his own election to heaven. Hugh had overcome the apparent obstacle of Moses's lack of justice and wrongful ordering of loves, and, in doing so, he had also resolved Gregory the Great's concern about Moses's improper attempt to deflect divine anger. On Hugh's account, Moses's intercession was not a challenge to God, because it was not really an 'intercession' at all: Moses had merely stated what he knew to be true of God - that he is both just and merciful. Moses, speaking out of 'indescribable love', desired the salvation of his people and trusted that the Lord would accomplish it.

Hugh's response offers some insight into why twelfth-century scholastic commentators felt compelled to explain, or at least carefully contextualise, this passage of scripture. The problem did not lie in the apparent justice or injustice of God's decision to punish Israel, although this was more generally a popular topic of discussion in scholastic summae, with many texts carefully examining the justice of each and every one of God's sentences. ${ }^{27}$ Divine mercy towards sinners could equally be explained. ${ }^{28}$ Nor was the intercession of a leader on behalf of his people an inherently unjust or problematic act. Rather, the offence to divinely-ordered justice lay in the nature of Moses's intercession, in the form of his words and the apparent 'ultimatum' he had made to the Lord. Moses could be understood as interceding for something manifestly unjust: the damnation of a good man (the loss of his own soul) in exchange for the salvation of a sinful people. ${ }^{29}$ This was contrary to

\footnotetext{
${ }^{27}$ See Jacques Le Goff, The Birth of Purgatory, trans. Arthur Goldhammer (London: Scolar Press, 1984), pp. 135-42, 210-20.

${ }^{28}$ For instance, the English theologian Robert Pullen discussed the sins of the Israelites and the punishments due to them, but noted that that they did not deserve complete damnation and in fact received mercy from the Lord. Sententiarum Libri Octo, 3:8; PL 186:772-73.

${ }^{29}$ M.S. Kempshall, The Common Good in Later Medieval Political Thought (Oxford: Oxford University Press, 1999), pp. 293-315. No scholastic theologian was willing to condone the idea that one should sacrifice one's own soul, and thus union with God, for the good of the community, however that community may be constituted.
} 
justice in the sense that it seemed to imply that an innocent man was willing to take upon himself the punishment incurred by a guilty people, thus offending the idea that God would return to each according to his works (secundum opera).$^{30}$ Yet even more seriously, it ran contrary to a greater sense of justice: the Israelites had committed an offence against God in their idolatry, and to ask that their sin be forgiven was in essence to compound that offence.

One way of underscoring exactly what was new and peculiarly scholastic about this concern with the justice of Moses's action is to consider the treatment of the intercessory episode in the writings of a much more 'traditional' theologian, the Benedictine Rupert of Deutz (c. 1075/80-c. 1129). Whilst it is anachronistic to see an absolute contrast and dramatic break between the 'old', meditative theology of the cloister and 'new' dialectical theology of the schools, it is fair to say that Rupert was far more interested in traditional exegetical techniques than the application of dialectical learning to scripture. ${ }^{31}$ Rupert, a decade or so older than Hugh of St Victor, had relatively little exposure to the avant-garde techniques practiced in the new schools. ${ }^{32}$ In his great work, De sancta trinitate et operibus eius (composed between 1113 and 1116), ${ }^{33}$ essentially a history of salvation in forty-two books, Rupert devotes an entire book to examining Exodus, and, within it, chapter 32. However, when it comes to considering the reasoning underpinning Moses's intercession, Rupert glosses the episode quite differently to his contemporaries in the schools. What Moses means by 'either delete me or spare them' is not to be interpreted as a complex challenge to the ordained order of predestination, nor is it a puzzle of language: it is rather a powerful didactic statement, through which scripture indicates that all men are sinners. 'Delete me',

\footnotetext{
${ }^{30}$ e.g. Matt. 26:27, filius enim hominis venturus est in gloria Patris sui cum angelis suis: et tunc reddet unicuique secundum opera eius.

${ }^{31}$ A contrast famously characterised in Jean Leclercq, The Love of Learning and the Desire for God: A Study of Monastic Culture (London: SPCK, 1974).

${ }^{32}$ On Rupert's education see John van Engen, Rupert of Deutz (Berkeley, CA: University of California Press, 1983), pp. 42-8. For Rupert's theological works see pp. 95-134.

${ }^{33}$ For the dating of the work, van Engen, Rupert of Deutz, pp. 131-34.
} 
Rupert asserts, was a phrase spoken to indicate that Moses himself was a sinner. The patriarch wished that, if God was prepared to punish the Israelites, he ought not to neglect to punish Moses himself, because he was not free from sin either. The meaning of Moses's speech, on Rupert's reading, is as if he had announced 'I, too, am a sinful man' (homo peccator sum). ${ }^{34}$ If God destroys the Israelites, he will demonstrate that his judgement is without mercy, and this being so, it follows that God should spare no man, not even Moses (and thus his name must be removed from the Book of Life). The didactic point Rupert seems interested in making is that all humans should be conscious of their own sins, which are recalled by God and for which they will be obliged to give account on the Day of Judgement. ${ }^{35}$ Rupert interprets the entire passage as a moral call to confession and repentance, emphasising the frightening reality and centrality of divine judgment of sin for his readers.

Rupert had no interest in dealing with Exodus 32 as an affront to divine justice, and the problem is relatively easily resolved, and turned into a straightforward and instructive example. Yet only a generation later, questions concerning the justice of Moses's intercession were at the forefront of discussion in the schools of northern France. In part, this was a product of the increasing academic scrutiny to which sacred scripture was exposed from the eleventh century onwards. The development of the dialectical method focused attention on the apparent contradictions of scripture. ${ }^{36}$ But a simple increase in the number of scholars reading and examining scripture and the proliferation of commentaries upon it does not, on

\footnotetext{
${ }^{34}$ Rupert of Deutz, De sancta trinitate et operibus eius: In Exodum IV, ed. H. Haacke, CCCM 21-24 (4 vols., Turnhout: Brepols, 1971-2), ii, pp. 784-8. The phrase 'homo peccator sum' is invoked by Rupert in a deliberate echo of Luke 5:8, the words Simon Peter uses to explain to Christ why he is unworthy to be his disciple.

${ }^{35}$ De sancta trinitate: In Exodum IV ; ed. Haacke, ii, p. 786.

${ }^{36}$ See David E. Luscombe, 'Dialectic and Rhetoric in the Ninth and Twelfth Centuries: Continuity and Change', in Johannes Fried (ed), Dialektik und Rhetorik im frühen und hohen Mittelalter: Rezeption, Überlieferung und gesellschaftliche Wirkung antiker Gelehrsamkeit vornehmlich im 9. und 12. Jahrhundert (Munich: R. Oldenbourg, 1997), pp. 1-20; Marcia L. Colish, '...Quae hodie locum non habent: Scholastic Theologians Reflect on their Authorities', in Philip Pulsiano (ed.), Proceedings of the PMR Conference 15 (Villanova, PA.: Augustinian Historical Institute, 1991), pp. 1-17.
} 
its own, explain the twelfth-century change. Twelfth-century commentaries indicate a particular interest in the justice of Moses's actions. Although it is too simplistic to draw a straightforward connection between contemporary societal changes in the development of particular arguments in scholastic theology, these twelfth-century examinations of Exodus 32 do need to be set against a backdrop of significant legal change. This, the moment of a 'revolution in law', at which canon and civil law systems were beginning to be articulated, was a moment at which the precise meaning of justice mattered. ${ }^{37}$ Increasing attention was being paid to judicial standards of conduct, with both theologians and lawyers concerned with the problem of judicial partiality. ${ }^{38}$ How could any system ensure that judgement was made in accordance with the merits of the case, rather than dictated by the personal biases of the judge? Simultaneously, the place of divine justice within secular legal system was under scrutiny, as criticisms of the role of the judicial ordeal increased ${ }^{39}$ In short, the theological and legal innovations of the twelfth century created a climate in which standards of justice whether historical, ecclesiastical, secular or soteriological - were up for discussion. This provides a context which must be borne in mind when considering the distinctive focus of scholastic commentaries on Exodus 32.

\section{SCHOLASTIC SOLUTIONS: ROBERT OF MELUN AND PETER COMESTOR}

Scholastic examinations of Exodus 32 support the characterisation of scholastic thought as an endeavour primarily concerned with the precision of language and the

\footnotetext{
${ }^{37}$ For this argument see Harold J. Berman, Law and Revolution: The Formation of the Western Legal Tradition (Cambridge, MA: Harvard University Press, 1983).

${ }^{38}$ See E.J.H. Schrage, 'Judex bonus vir dicitur: On the Role of the Holy Scriptures in Medieval Writings on the Law of Procedure', English Historical Review 13 (1992), pp. 128-46.

${ }^{39}$ Robert Bartlett, Trial by Fire and Water: The Medieval Judicial Ordeal (Oxford: Blackwell, 1986). See also John W. Baldwin, 'Critics of the Legal Profession: Peter the Chanter and his Circle', in Stephan Kuttner and John Joseph Ryan (eds.), Proceedings of the Second International Congress of Medieval Canon Law (Vatican City: S. Congregation Seminariis et Studiorum Universitatibus, 1965), pp. 249-59.
} 
application of logical reasoning to scripture. ${ }^{40}$ But interest in Moses's intercession represented more than an intellectual challenge. Scholastic theologians felt a compelling need to explain Moses's behaviour in order to defuse an exemplum which, if construed wrongly, had the potential to impugn either the propriety of the patriarch, or, indeed, that of the Lord. Two instructive examples of this approach are evident in the works of Robert of Melun and Peter Comestor, whose discussions expand on the questions raised in Hugh of St Victor's discussion of Exodus.

Robert of Melun (c. 1100-67), Parisian theologian and Bishop of Hereford, was praised by John of Salisbury (his former pupil) as one of the greatest dialecticians of his day. ${ }^{41}$ It is not, therefore, particularly surprising that Robert should have chosen to address the logical paradox of Moses's intercession. He does so in his Quaestiones de divina pagina, a collection of 125 questions which mostly examine problems arising from the Gospel of Matthew. When considering Exodus 32, Robert simply begins by asking whether Moses's request, in pleading for his people, was just (iustus). ${ }^{42}$ Robert understands Moses words as an unjust request, 'because there is nothing more unjust than wanting to be separated from God', even for the sake of one's own people. Robert then argues that, had Moses believed God would not spare his people, he would not then have wished to be separated from God - that is, Moses would not have put his own salvation at risk had he not been confident in the power of his words to move the Lord to mercy. Robert considers what can be understood from Moses's manner of speech: his words show the ardour of his affection for the Israelites, but more importantly, they demonstrate the special manner in which Moses conversed with God.

\footnotetext{
${ }^{40}$ For a general characterisation see Marcia L. Colish, 'Systematic Theology and Theological Renewal in the Twelfth Century’, Journal of Medieval and Renaissance Studies 18 (1988), pp. 131-56.

${ }^{41}$ For an introduction to his life and works see D.E. Luscombe, The School of Peter Abelard: The Influence of Abelard's Thought in the Early Scholastic Period (London: Cambridge University Press, 1969), pp. 281-98; B. Smalley, The Becket Conflict and The Schools: A Study of Intellectuals in Politics (Oxford: Blackwell, 1973), pp. 51-8.

${ }^{42}$ Robert of Melun, Questiones de divina pagina, ed. R.M. Martin (Louvain: Spicilegium Sacrum Lovaniense, 1932), q. 62, pp. 32-3.
} 
The conversation between the Lord and his prophet was like that between a father and a son. This is the central point of Robert's analysis: knowing that God loved him as a father loves a son, Moses hoped that paternal love would fulfil a request so patently contrary to justice. True to the dynamics of this special relationship, the Lord, moved by Moses's piety, spared the guilty Israelites.

Robert's answer to the question is thus fairly short, but far from entirely straightforward. Whilst he concedes that Moses's request was unjust, he goes somewhat beyond the remit of his original question to explain why the request was granted. Indeed, just how complex a problem this was is indicated by the fact that Robert attempted to 'solve' it on several occasions. In a second series of questions on the letters of Paul, Robert returns to the problem of Moses's intercession when commenting on Romans $9 .{ }^{43}$ However, as we cannot say which of the texts - the Quaestiones de divina pagina or the Questiones de Epistolis Pauli - was composed first, and both can be dated no more specifically than between 1145 and 1157, we cannot speak of a 'development' in Robert's thinking.

For scholastic theologians, Romans 9 presented an exegetical problem strikingly similar to that of Exodus 32. It is in his letter to the Romans that the apostle Paul exclaims that he would be willing to be cursed and cut off from Christ for the sake of his brothers (anathema fieri propter fratres). ${ }^{44}$ This, in turn, raised the question of the proper ordering of the apostle's loves, for, naturally, Christ is to be preferred above all other brothers. To be separated from Christ would mean a spiritual death, to be denied salvation. As with Moses, the issue was again that a holy man, a spiritual model for Christians, was suggesting he

\footnotetext{
${ }^{43}$ Robert of Melun, Questiones de Epistolis Pauli, ed. R.M. Martin (Louvain: Spicilegium Sacrum Lovaniense, 1938), p. 42.

${ }^{44}$ Carolingian authors, including Alcuin and Haimo of Auxerre, had drawn a connection between Paul and Moses, because both were 'lawgivers' (Paul delivers the new covenant of Christ). See Archer St. Clair, 'A New Moses: Typological Iconography in the Moutier-Grandval Bible Illustrations of Exodus', Gesta 26:1 (1987), pp. 19-28. Rupert of Deutz also draws the connection between Moses and Paul, although he is not interested in the 'justice' of Paul's request, but rather in the didactic point made by the admirable caritas that both Moses and Paul demonstrate by their words, which earned them further grace with God. De sancta trinitate: In Exodum IV, iv, pp. 786-7.
} 
wished for something contrary to his own salvation, and therefore contrary also to divine justice. Surely this was not something which the apostle ought to have desired? ${ }^{45}$

Robert of Melun begins his analysis of Romans 9 by asking how the apostle could desire something which he knew ran contrary to all justice, and then provides his solution. As Robert understands it, there are two ways of interpreting Paul's utterance. The first solution is simply to assume that Paul was expressing a desire to be separated from God only for a time, for the sake of his brothers. Robert infers that Paul sought an earthly, physical separation from the Church and its practices, not an eternal separation lasting into the next life. This time would be a period of exile amongst the unconverted of Israel, during which Paul would preach to them, and, most importantly, attempt to bring the unproselytized to God. The separation, then, would be only temporary, not a genuine severance from Christ and salvation. On this reading, Romans 9 does not depict Paul offering up his soul to win the salvation of others.

Robert does not explicitly criticise or reject this first explanation, but simply notes that he can offer a better (melius) reading. This is that Paul had employed these words to demonstrate the affection he held for his brothers. Following the interpretation of Ambrosiaster, Robert scrutinises Paul's grammar. When the apostle had seemingly expressed a wish to be cut off from Christ, he had used the verb 'optabam' rather than 'opto'. ${ }^{46}$ Anything expressed in an imperfect mode of speech (optabam) is understood as expressing an incomplete will, not a true or definite desire. ${ }^{47}$ The significance of that choice was the distinction between a thought Paul entertained temporarily, and his settled wish. The

\footnotetext{
${ }^{45}$ For further contemporary discussion of the justice of Paul's request see Simon of Tournai, Les Disputationes de Simon de Tournai, ed. J. Warichez (Louvain: Spicilegium Sacrum Lovaniense, 1932); Disputatio, 12.2; p. 46. ${ }^{46}$ Ambrosiaster, Commentaria in Epistolam ad Romanos, PL 17.131; Robert of Melun, Questiones de Epistolis Pauli, pp. 117-18. The thirteenth-century Dominican friar Remigio dei Girolami repeats this point in his own discussion of Moses and Paul: see Kempshall, The Common Good, p. 306.

${ }^{47}$ A point later expanded on by Philip the Chancellor, commenting on the same passage, in his Summa de Bono (c.1230), ed. N. Wicki (2 vols., Berne: Francke, 1985), 2. 226, pp. 92-7. The later development of this idea is discussed at length in Risto Saarinen, Weakness of Will in Medieval Thought: from Augustine to Buridan (Leiden: Brill, 1994), pp. 81-2.
} 
seemingly minor grammatical difference indicates that Paul knew he ought not to wish to be separated from Christ, and indeed, this was not something he wished for. It is here that Robert introduces the comparison with Moses: Moses had demonstrated the affection he held towards sinful Israel when asking to be blotted out of the Book of Life, and Paul spoke in the same way. Neither of them truly desired their requests - their words stand as rhetorical flourishes. Robert notes that such a thing is common in human speech. Such illogical statements are passionate outbursts which indicate the intensity of underlying affection, but are not to be read as considered statements of intent. Like Hugh of St Victor, Robert explains and resolves the problem by drawing a distinction between the desperation and immediacy of pleading and the precision of theological discourse. Robert now argues that Moses was simply saying what he would have liked to be true, but knew was impossible. In concluding in this way, Robert of Melun had devised at least two ways in which the text of Exodus 32 could be understood, even offering a third alternative explanation when discussing the case of St Paul. This ability to draw out different possible solutions is very much in keeping with what Robert's student, John of Salisbury, described as his characteristic practice: as a scholar, Robert could never end a discussion without first setting forth the opposing arguments in the case, and was never content to give a single answer to a question. ${ }^{48}$

Robert's emphasis on the need to understand the human, emotional context in which the words of scripture were first spoken is repeated in another influential twelfth-century text, the Historia scholastica of Peter Comestor, the Chancellor of Notre Dame and leader of the cathedral school there. ${ }^{49}$ In the Historia (c. 1170), Peter explains Moses's actions at Exodus 32 by arguing that he spoke 'de impetu animi, non de ratione', from passion, rather than reason. ${ }^{50}$ For Peter too, any prospect of Moses actually being deleted from the Book of Life

\footnotetext{
${ }^{48}$ John of Salisbury, Metalogicon, ed. J.B. Hall, CCCM 98 (Turnhout: Brepols, 1991), 2.10.13, p. 71.

${ }^{49}$ For the Historia scholastica and its reception, James H. Morey, 'Petrus Comestor, Biblical Paraphrase and the Medieval Popular Bible', Speculum 68:1 (1993), pp. 6-35.

${ }^{50}$ Peter Comestor, Historia scholastica, PL 196:1190-1.
} 
must be dismissed as entirely unjust, and consequently impossible. Indeed, he explains such an action would have been contrary to justice when measured according to either of two standards: it was unjust both according to God's foreknowledge (praescentia), and according to his justice (iustitia). According to foreknowledge, the identities of the damned and the saved have been known to the Lord since the beginning of time. Thus, just as Paul was destined for salvation (i.e. his name was recorded in the Book of Life) even when he persecuted the Church before his conversion, so Moses's name could not be erased from the Book. Equally, according to justice, it would not be just to punish the innocent for sins which were not their own, and allow Moses to transfer the sins of the Israelites to his own leger. Therefore, Peter pronounces, Moses must have known that he would never be deleted from the Book of Life.

Peter concludes his discussion by tying his own arguments to patristic interpretations of the passage. He returns to, and expands upon, Augustine's discussion of the meaning of Moses's request. Peter does not cite a specific Augustinian work, but he appears to have been thinking of the Quaestiones in Heptateuchum. ${ }^{51}$ There Augustine had explained that the effect of Moses's words had been to create a condition: 'either delete me or forgive them'. Thus the effect of these words was to express the proposition 'if you do not delete me, then forgive them'. Following that reasoning, Peter explained that as God could not and would not condemn Moses to damnation, it followed that he would, in fact, forgive the Israelites. ${ }^{52}$ Moses could make this statement precisely because he knew that God would not destroy him; and as God would not destroy him, so he was confident that God would spare the Israelites. By carefully exploring the status of words, syntax and their implications, Robert and Peter framed the incident of the intercession as perfectly compatible with the workings of divine

\footnotetext{
${ }^{51}$ Quaestiones in Heptateuchum, 147; PL 34:645.

52 This passage too was later utilised by Remigio dei Girolami, Kempshall, The Common Good, p. 305.
} 
justice, and warned that it was, effectively, a 'one-off': an action never to be imitated, and an incident which did not provide any sort of precedent or support for challenging divine justice in the present day.

\section{CONCLUSION}

The difference between the analyses of Exodus 32 provided by early medieval exegetes and those of twelfth-century theologians is both quantitative and qualitative. They mark a quantitative change in that the twelfth-century schools devoted a great deal of ink and attention to scrutinising the incident of the intercession. They mark a qualitative change, in that those commentaries treated Moses's actions as something more than a puzzle in scriptural history. Theologians saw not a simple inconsistency which invited swift clarification, but an exemplary incident which provided a glimpse into the workings of divine justice, predestination and issues of equitable punishment. Their desire to account for the apparent contradiction sprang from the instructive value of Exodus 32 to a society in the process of defining the difference, and the dividing line, between temporal and divine justice. Indeed, it is tempting to see in scholastic discussions of Moses's intercession a parallel with contemporary debates regarding the status and validity of the judicial ordeal. ${ }^{53}$

Scholastic and canonist opposition to the ordeal in the years before 1215 coalesced around the principle that the ordeal ran contrary to divine justice - it challenged and offended the Lord by demanding his constant intervention in human affairs to provide a verdict on matters of temporal concern. ${ }^{54}$ Yet theologians and canonists convinced that the ordeal represented an unjust procedure had then to explain the incidents in biblical history in which

\footnotetext{
${ }^{53}$ For the theological arguments, J.W. Baldwin, 'The Intellectual Preparation for the Canon of 1215 Against Ordeals', Speculum 36 (1961), pp. 613-36.

${ }^{54}$ Baldwin, 'Intellectual Preparation', p. 628.
} 
appeared to sanction its use and legitimacy. ${ }^{55}$ The preeminent intellectual task for any twelfth-century master in divina pagina was to discern the distinction between history and legal precedent, the difference between history and exemplary history. ${ }^{56}$

The same underlying questions which drove discussion of the validity of the ordeal can be seen in scholastic analyses of Exodus 32: what precedent and sanction can scriptural examples of justice or judicial procedure provide for human legal systems? These two topics - the role of God in the ordeal, and the justice of Moses's intercession - served, at least in part, to define the dividing lines between human and divine justice. The scholastic verdict was, typically, that Moses's words and pleading could have had no effect on God's eternal justice. Just as criticism of the ordeal defined the boundary between the miraculous and the mundane, between divine justice and human procedure, so too did scholastic analyses of Exodus 32 demonstrate the vast gulf between human desires and divine judgement. Even the great Moses had been given the power to punish or forgive only in the saeculum - his pleading could not alter the immutable verdict of divine justice.

Twelfth-century interest in Moses's intercession for his people was, of course, not limited to scholastic treatises. The topos of Exodus 32 recurs frequently in letters, homilies, and hagiography. ${ }^{57}$ The idea of a sinless man interceding for his guilt-ridden people was clearly a powerful and appealing image. ${ }^{58}$ What makes the scholastic examination of Exodus 32 so significant, however, is the context of those analyses. The biblical incident provided an interpretative key to understanding the nature and shape of justice. In turn, the conclusions of those analyses could provide instruction about how, when, and why mercy should be sought.

\footnotetext{
55 For example, Numbers 5:12-28, which describes the 'ordeal of bitter waters', a process by which men may invoke the judgement of God in order to discover whether their wives are guilty of adultery.

${ }^{56}$ On this point see Bruce C. Brasington, 'Non imitanda sed veneranda: The Dilemma of Sacred Precedent in Twelfth-Century Canon Law', Viator 23 (1992), pp. 135-52.

${ }^{57}$ For example, Bernard of Clairvaux, Sermones in Cantica, 30.4; PL 183:935C; Bernard, Ep. 118.2; PL 182:192; Hugh of St. Victor, De sacramentis, 2.13.10; PL 176:537.

${ }^{58}$ David sparing his wicked people was also considered an instructive example of intercession for twelfthcentury kings: Orderic Vitalis, Historia Ecclesiastica, ed. and trans. M. Chibnall (6 vols., Oxford: Oxford University Press, 1969-80), 8, iv, pp. 126-9.
} 
So much of twelfth-century literature turns to scripture to provide models for living, particularly for rulers, who are exhorted to imitate David, to look to Josiah, to be a second Daniel. But it was equally vital that scholastic masters identify the cases to the contrary: the parts of scripture which were not to be imitated. This category was not limited to the obvious 'rogues gallery' of bad examples - Cain, Nebuchadnezzar and Judas. There were occasions when even good Christians should not - indeed, could not - try to follow the example set by an individual as virtuous as Moses. In letters, in hagiography, in stone and in glass, the figure of Moses interceding for the Israelites was a popular image. But twelfth-century scholastic theology inserts a small but significant exception to this, drawing a cordon sanitaire around Exodus 32, and issuing a warning against uncritical admiration: Moses could not be allowed to set a dangerous precedent. 